\title{
SEX DETERMINATION AND LARVAL SEXUAL INTERACTION IN BONELLIA VIRIDIS Rolando (ECHIURA : BONELLIIDAE)
}

\author{
V. JACCARINI ${ }^{1}$, L. AgIUs ${ }^{2}$, P. J. Schembri ${ }^{3}$ and M. Rizzo ${ }^{4}$ \\ The Fort St. Lucian Marine Station. The University of Malta, Malta
}

\begin{abstract}
Sex determination in the echiuran Bonellia viridis Rolando has classically been regarded as depending primarily on the environment of the newly settled larvae. The majority of the sexually undifferentiated larvae settling on an adult female become males; the larvae which settle away from the adult female become females in most cases. Previous work on this problem is reviewed.

The behaviour, including the time-course of settlement, and the development of the indifferent larvae of $B$. viridis in the presence and absence of an adult female is described. Evidence is provided that even in the absence of adult females there is an interaction between newly settled larvae such that up to $20 \%$ of larvae become attached to one another in pairs with masculinization of one partner, the other developing into a female.

Using larvae cultured singly, it was shown that crude extracts of adult female proboscis and trunk body-wall and the pigmented secretion of an irritated female masculinize indifferent larvae, the vast majority of which would have developed into females in pure sea water. Solutions of the purified integumentary pigment, bonellin, gave inconsistent results. Our experiments prove conclusively that sex determination is metagamic, i.e., not fixed at fertilization but is the result of an interaction between genetic and environmental factors, in $\approx 83 \%$ of all larvae. The main environmental factor is a substance produced by the female. The other $17 \%$ are larvae whose sex is determined exclusively by their genetic make-up. These are syngamic males, females and intersexes. The problem of indefinitely undifferentiated larvae is discussed.
\end{abstract}

\section{INTRODUCTION}

The work of Baltzer $(1914,1924,1925,1928,1931$ a, 1932) on sex determination in Bonellia viridis Rolando established this echiuran as a classical example of environmental, and metagamic sex determination, i.e., the direction of sexual differentiation is not fixed at fertilization but at a subsequent stage. The vast majority of the indifferent larvae of Bonellia differentiate into females if cultured in the absence of adult females, and differentiate into males when cultured with adult females. Using vitally stained proboscides, Baltzer (1914) showed that the larvae which attach to the proboscis of an adult female take up stain from it, and by experimentally shortening the time of attachment a high percentage of intersexes was obtained, the degree of masculinization being directly related to the duration of attachment (Baltzer, 1931a; Zurbuchen, 1937).

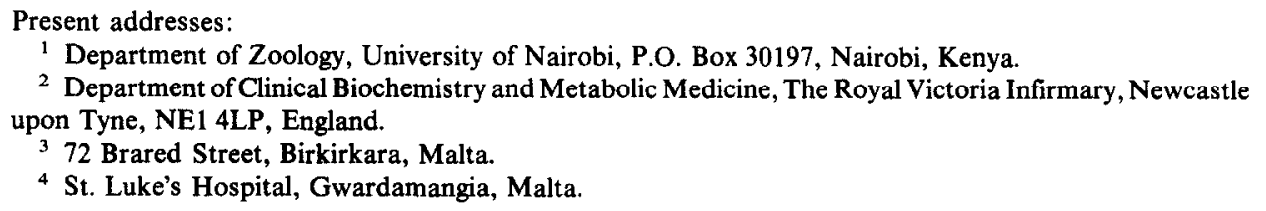


Loosli (1935) made a histological study of the organ of attachment. Baltzer concluded that a substance produced by the adult female induces masculinization. Baltzer also established that a small percentage of individuals metamorphosed into males or females irrespective of their environment. Wilczynski $(1960,1968)$ claimed that the unfertilized eggs were cytologically dimorphic with a $1: 1$ ratio, the implication being that sex determination was syngamic, i.e., established at fertilization. Leutert (1974) using electron microscopy failed to find any egg dimorphism. He also repeated Baltzer's experiments using much larger numbers of eggs, and analyzing the results statistically concluded that sex was determined metagamically in the overwhelming majority of individuals.

Various workers (Baltzer, 1925, 1926; Nowinski, 1934; Mutscheller, 1935) found that aqueous extracts of dried proboscis as well as gut of adult female Bonellia masculinize indifferent larvae. Herbst $(1928,1929,1932,1935,1936,1937)$ showed that elevated levels of $\mathrm{CO}_{2}, \mathrm{H}^{+}$, and $\mathrm{Cu}^{2+}$ as well as subnormal levels of $\mathrm{Mg}^{2+}$ and $\mathrm{SO}_{4}^{2-}$ also masculinize. Agius (1979) compared the proportions of male larvae resulting from exposing the indifferent larvae to (1) the entire adult female; (2) the isolated proboscis; (3) the proboscidectomized female; (4) trunk body-wall extract; (5) proboscis extract; (6) gut extract; and (7) the trunk secretion of the adult female. She obtained statistically significant higher percentages of masculinized larvae with all these treatments than with the pure sea-water controls. The highest ratios of masculinization were obtained with the entire female and with its trunk secretion.

Bonellin is the main constituent $(94-98 \%)$ of the crude proboscis pigment extract, with amino-acid conjugates of bonellin as minor constituents. Trunk integument pigment extracts contained roughly equal amounts of free bonellin and its amino-acid conjugates

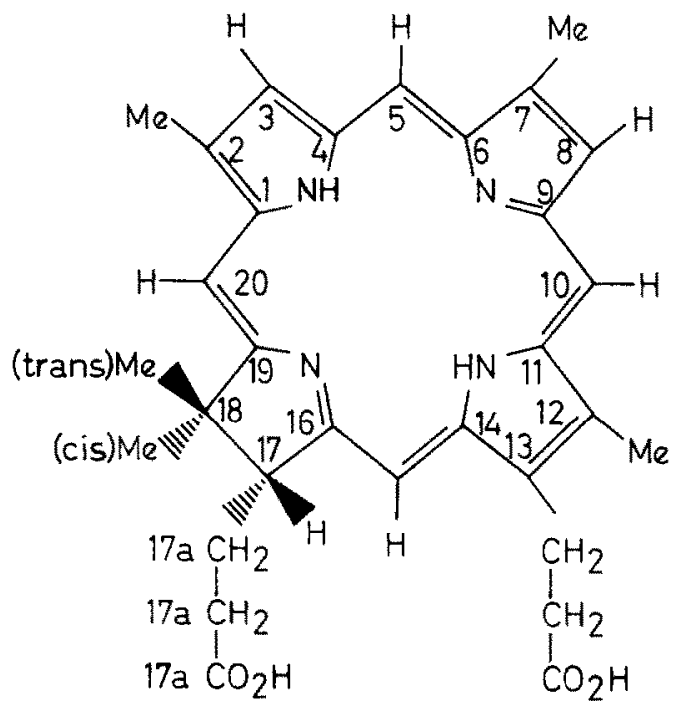

Fig. 1. Structure of bonellin. 
(Cariello et al., 1978; Pelter et al., 1978a). The copper complex of bonellin was another very minor constituent of the pigment extracts. The structure of bonellin (Fig. 1) has been fully established using mass spectroscopy, nuclear magnetic resonance, and X-ray diffraction techniques (Peiter et al., 1976, 1978b).

The aim of the present work is first, to investigate the nature of sex determination in Bonellia using larvae cultured individually wherever relevant, since we discovered early in our study that larvae interact with each other when cultured in batches. None of the previous workers had reported this interaction nor taken it into account in their analyses. Secondly, we investigate the nature and mode of action of the masculinizing substance. We focused our attention on bonellin, the green integumentary pigment of Bonellia, for the following reasons. (1) Preliminary observations had indicated that the larvae which settle on the adult female take up the green pigment from the female proboscis. (2) The pigment has been shown to have a wide range of biological activity - it is toxic to various small organisms, including, at high concentrations, the larvae of Bonellia itself (Baltzer, 1924, 1925); it cytolyses echinoid spermatozoa and embryos (Lallier, 1955; Schembri, 1977; Cariello et al., 1978; Agius et al., 1979); it inhibits carcinoma cells in vitro (Nigrelli et al., 1967); and highly purified crystalline bonellin, such as we proposed to use, has marked activity cytolysing haemocytes and interfering with echinoid fertilization and development, these effects being mediated by photodynamic action (Agius et al., 1979). (3) The pigmented trunk secretion of adult females had a very potent masculinizing effect on the indifferent larvae (Agius, 1979).

\section{MATERIAL AND METHODS}

Adult Bonellia viridis females were collected from Marsaxlokk Bay, Malta, and kept in circulating sea water at ambient temperatures. Spawning took place throughout the year under these conditions. The egg strings were removed from the female directly after laying and kept in aerated Millipore-filtered (pore size $0.45 \mu \mathrm{m}$ ) sea water. The trochophores hatched within $48 \mathrm{~h}$ from spawning at $20^{\circ} \mathrm{C}$. All experiments were started within 9 days from spawning. Only larvae from the same spawning were used in each experiment. Unless otherwise stated, all cultures were kept in the dark, except for as long as it took to make brief observations or to effect change of media.

\section{PREPARATION OF BONELLIN SOLUTIONS}

The source of bonellin was adult female proboscides. Crystalline bonellin of at least $98.5 \%$ purity was used. The extraction and purification have been described (Agius et al., 1979). The main impurities are $\approx 0.5 \%$ Cu-bonellinate, $0.01 \%$ Fe-bonellinate, and $1 \%$ amino-acid conjugates of bonellin (Ballantine et al., 1980). For Experiment 4A a weighed amount of bonellin (mol. wt. 526) was dissolved in a minimum quantity of $90 \%$ acetone. $10 \mathrm{ml}$ of Millipore-filtered sea water (pore size $0.45 \mu \mathrm{m}$ ) were mixed with acetone, and evaporated under reduced pressure in a rotary evaporator. The resulting 
solution of bonellin in sea water was diluted with filtered sea water to give the concentration required. Bonellin-free control solutions were prepared using the same volumes of acetone and sea water as above.

In Experiments 2, 3 and $4 \mathrm{~B}-\mathrm{D}$ bonellin was dissolved in the minimum volume $\left(\approx 0.2 \mathrm{mg} / \mathrm{ml}\right.$ ) of $0.1 \mathrm{M} \mathrm{Na}_{2} \mathrm{CO}_{3}$ and then diluted with sea water. The same amount of carbonate was added to the controls. Since preliminary experiments showed that bonellin solutions obey Beer's law below $5 \times 10^{-6} \mathrm{M}$ in phosphate buffer (ionic strength 0.2 ), the decay of the solutions was monitored by measuring the $E_{390}$ and correlating this with calibration curves. For most of the experiments the half-life of the solutions did not exceed $48 \mathrm{~h}$. The concentrations were restored to the starting values by the addition of a calculated volume of a concentrated bonellin solution.

\section{PREPARATION OF CRUDE TISSUE EXTRACTS}

Adult Bonellia were dissected to obtain separate preparations of trunk body-wall, proboscis and gut. The separate tissues were minced and homogenized in sea water. The crude "brei" was centrifuged and the supernatant diluted until its $E_{390}$ was of the same value as a $10^{-6} \mathrm{M}$ bonellin solution. The $E_{390}$ of the extracts was taken as an estimate of the concentrations of bonellin and its amino-acid conjugates which have the same absorption spectrum as bonellin.

\section{PREPARATION OF THE INTEGUMENTARY SECRETION}

An adult female Bonellia was irritated by gentle mechanical disturbance and a copious pigmented secretion was released. This was diluted with filtered sea water until its $E_{390}$ was of the same value as a $10^{-6} \mathrm{M}$ bonellin solution.

\section{ANALYSIS OF LARVAE}

All larvae were individually examined live under a stereomicroscope and then fixed. Eight characters (Table I) were used to determine the sexual status of the larvae: male, female, and intersex. The last category includes larvae showing a mosaic of male and female characters.

To study the behaviour and development of the indifferent larvae in the presence and absence of adult females (Experiment 1)

Batches of fifty 9-day-old trochophores were used. Two batches were cultured in clean aerated sea water in the absence of an adult female and two batches were placed in beakers each with an adult female. Daily observations using a stereomicroscope were made on the behaviour and development of the larvae. With the larvae placed with the adult females observations were continuous for the first few hours of the experiments. All cultures were maintained for 31 days at ambient temperature. At the end of this 
period the adult females were dissected and the number of metamorphosed larvae counted.

TABLE I

Characters of the sexually undifferentiated, fully male and female larvae of Bonellia viridis: intersexes show a mixture of male and female characteristics.

\begin{tabular}{|c|c|c|c|}
\hline \multirow[b]{2}{*}{ Character } & \multicolumn{3}{|c|}{ Type of larva } \\
\hline & $\begin{array}{l}\text { Indifferent } \\
\text { larva }\end{array}$ & Male & Female \\
\hline Ciliation & $\begin{array}{l}\text { All over the } \\
\text { body }\end{array}$ & $\begin{array}{l}\text { All over the } \\
\text { body }\end{array}$ & $\begin{array}{l}\text { On proboscis } \\
\text { only }\end{array}$ \\
\hline Trochal rings & Two & Absent & Absent \\
\hline Pre-oral region & $\begin{array}{l}\text { Moderately } \\
\text { developed }\end{array}$ & Much reduced & Hypertrophied \\
\hline Eyespots & Present & $\begin{array}{l}\text { Disappear } \\
\text { early }\end{array}$ & $\begin{array}{l}\text { Disappear } \\
\text { much later }\end{array}$ \\
\hline Intestine & $\begin{array}{l}\text { Closed sac } \\
\text { with yolk }\end{array}$ & $\begin{array}{l}\text { Closed sac } \\
\text { with yolk }\end{array}$ & $\begin{array}{l}\text { Well developed } \\
\text { with mouth and } \\
\text { anus }\end{array}$ \\
\hline Coelom & Absent & Narrow & Spacious \\
\hline Anal sacs & Absent & Absent & Present \\
\hline Locomotion & Free-swimming & Ciliary creeping & Peristaltic \\
\hline
\end{tabular}

To investigate the interaction of larvae in batch culture (Experiment 2)

Experiment 1 showed that up to $20 \%$ of larvae in batch culture in the absence of adult females attached themselves to other larvae, one member of the attached pair differentiating into a male and the other into a female. Experiment 2 was designed to investigate the extent of this interaction between larvae in batch culture. Ten replicate batch cultures of fifty 6-day-old larvae were set up each in $200 \mathrm{ml}$ of filtered sea water. The larvae from a single spawning were randomized as far as possible by stirring the water before sucking up the individuals into a pipette for transfer into the culture beakers. The following day 99 randomized larvae from the same spawning as before were set up individually in separate specimen tubes with sea water. All cultures were maintained at $20 \pm 1{ }^{\circ} \mathrm{C}$ in the dark. The cultures were examined at intervals and terminated 51 days after spawning. The larvae were classified into three groups: males, females, intersexes plus indifferent. The number of males attached to female larvae was noted. 
To compare the effects of bonellin with those of crude tissue extracts of the adult female and those of its external body-wall secretions (Experiment 3)

Fifty 4-day-old larvae were cultured individually at $18 \pm 1^{\circ} \mathrm{C}$ in (1) $10^{-6} \mathrm{M}$ bonellin in sea water; (2) proboscis tissue extract; (3) trunk body-wall tissue extract; (4) trunk secretion; and (5) pure sea water. The bonellin solutions were restored every $48 \mathrm{~h}$. The experiment was terminated after 57 days.

To investigate the effects of bonellin under different conditions (Experiments $4 A-D$ )

Since Experiment 3 gave some indication that bonellin may be involved in masculinization, bonellin was tested under different conditions of temperature and illumination. In each instance 50 experimental cultures of single larvae in sea-water bonellin solutions and an equal number of pure sea-water controls were set up as follows.

(A) Five-day-old larvae in $2 \times 10^{-7} \mathrm{M}$ bonellin at $25-26^{\circ} \mathrm{C}$. The solutions were changed twice and the experiment was terminated after 27 days.

(B) Three-day-old larvae in $10^{-6} \mathrm{M}$ bonellin at $18 \pm 1^{\circ} \mathrm{C}$. The bonellin concentrations were restored every $48 \mathrm{~h}$ and the experiment terminated after 64 days.

(C) Four-day-old larvae in $10^{-6} \mathrm{M}$ bonellin at (1) $20^{\circ} \mathrm{C}$, and (2) $17^{\circ} \mathrm{C}$. Bonellin concentrations were restored every $48 \mathrm{~h}$ and the experiment terminated after 68 days.

(D) Since bonellin was known to be photodynamically active the following experiment was done. Five-day-old larvae were cultured at $20 \pm 1{ }^{\circ} \mathrm{C}$ under conditions of room illumination ( $\approx 400$ lux) in (1) $10^{-6} \mathrm{M}$ bonellin; (2) $4 \times 10^{-7}$ bonellin; and (3) pure sea water. Control cultures in (1) to (3) were kept in total darkness except for changing media at 10-day intervals in faint light. The experiment was terminated after 24 days.

\section{RESULTS}

BEHAVIOUR AND DEVELOPMENT OF INDIFFERENT LARVAE IN THE PRESENCE OF ADULT FEMALES

Ten minutes after they were introduced into beakers containing an adult female $40 \%$ of the 9-day trochophores had settled on the proboscis of the adult. Settlement is heaviest on the terminal lobes and near the junction of the lobes to the stem of the proboscis. Gradually up to $98 \%$ of the larvae settle on the female. Within $2 \mathrm{~h}$ of settling on the female the larvae had become very flattened dorso-ventrally and the pre-oral region had visibly shortened. The larvae do not attach by their entire ventral surface but only by a restricted area involving the prototroch. This observation is in agreement with that of Loosli (1935). The cilia covering the body still beat normally but the large cilia of both trochal bands had stopped beating. By 3 days after settlement the larvae look very much like mature males. The gut never opens to the exterior but the large yolk deposit of the trochophore is gradually used up. The eye spots have disappeared and the bright pigmentation which covered the whole body of the trochophore is now very 
much reduced. The larvae become progressively elongated and depressed and pigmentation becomes restricted to two small areas, one close to the anterior end and other near the posterior. The remaining pigmentation is lost by 5 to 6 days from settlement. During Days 6 to 8 the males move freely on the proboscis of the adult female in the general direction of the mouth, which is situated at the base of the stem of the proboscis. The sites on the proboscis vacated by the attached males are left devoid of pigment. By Day 7 most of the males have migrated into the pharynx and foregut of the female. For another 2 days the males move in and out of the mouth but by Day 10 no males are seen on the outside of the female. At least some of the males eventually take up residence in the androecium of the female oviduct. One female was dissected on Day 12 and of the almost 50 males which had migrated into the female, only 4 were found in the androecium, the rest were still in the pharynx of the female. Possibly after the first few individuals arrive at the androecium, any other males are prevented from entering. It would be interesting to find out if there is a turnover of males in the androecium. The density of males in the vicinity of an adult female in our experiment must presumably have been appreciably higher than that encountered in nature. We did not establish how the males migrate from the foregut to the androecium. The simplest way would be for the males to crawl from the mouth to the mid-ventral gonopore a few millimetres behind the mouth.

BEHAVIOUR AND DEVELOPMENT OF INDIFFERENT LARVAE CULTURED IN THE ABSFNCF OF ADULT FEMALES

Fig. 2 gives the time course of settlement of the indifferent larvae cultured in the absence of adult females. Our observations are in general agreement with those of

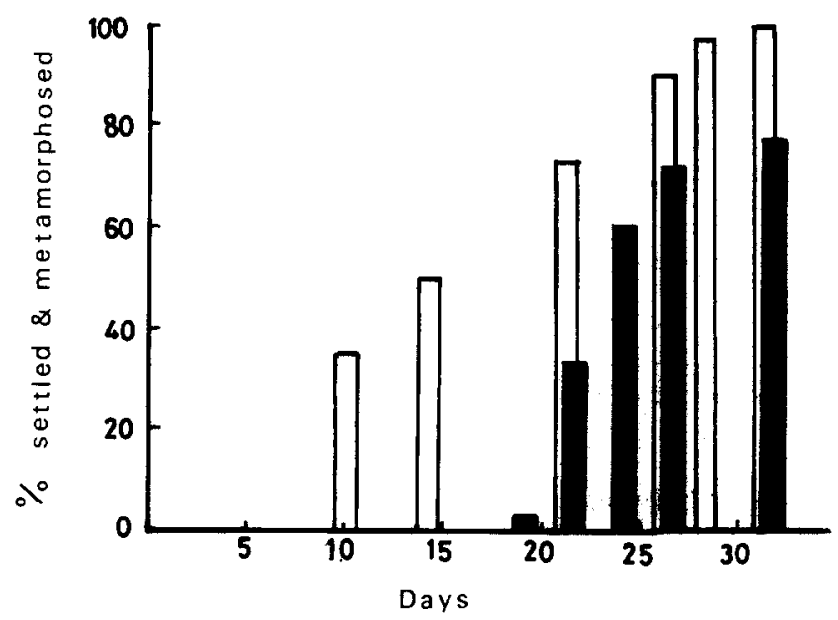

Fig. 2. The percentage of larvae of Bonellia viridis which settled (open rectangles) and metamorphosed (closed rectangles) when cultured in sea water in the absence of adult females: two batches each of 50 nine-day-old trochophores were used; the experiment was terminated after 31 days. 
Spengel (1879) and Baltzer (1925) with one very important exception, namely, up to $20 \%$ of larvae become attached in pairs; one member of each pair differentiating into a female and the other into a male. In one instance a newly metamorphosed male was found inside a female hardly larger than itself.

Another interesting observation is that just before final settlement the larvae show a characteristic "nosing" behaviour which is presumably exploratory in function. This consists of crawling with the ventral surface of the anterior half of the body applied to the substratum the posterior half being held up in the water. At this stage the larvae start to lose their original positive phototaxis and settle in loose aggregates. The larvae will now swim only if disturbed.

\section{LARVAL INTERACTION}

Experiment 2 was designed to measure the extent of the interaction of larvae revealed in Experiment 1 by comparing the results of culturing single larvae in pure sea water with those obtained when the larvae were cultured in batches. The results (Table II) confirm

TABLE II

Experiment 2: results of culturing 6- to 7-day-old Bonellia viridis larvae in sea water; $\mathrm{A}$, isolated individuals $B$, in batches; temperature $20 \pm 1^{\circ} \mathrm{C}$; experiment terminated after 45 days.

\begin{tabular}{rcccccc}
\hline & $\begin{array}{c}\text { No. of } \\
\text { larvae }\end{array}$ & Survivors & Females & $\begin{array}{l}\text { Single } \\
\text { males }\end{array}$ & Attached & $\begin{array}{c}\text { Intersex or } \\
\text { indifferent }\end{array}$ \\
\hline A & & & & & & \\
& 99 & 88 & 78 & 2 & & $8^{\mathrm{a}}$ \\
\hline B & & & & & & \\
1 & 50 & 28 & 14 & 6 & 5 & 3 \\
2 & 50 & 45 & 32 & 3 & 3 & 7 \\
3 & 50 & 32 & 17 & 8 & 4 & 3 \\
4 & 50 & 34 & 19 & 5 & 6 & 3 \\
5 & 50 & 30 & 27 & - & - & 10 \\
6 & 50 & 33 & 23 & - & - & 6 \\
7 & 50 & 38 & 23 & 5 & 4 & 9 \\
8 & 50 & 41 & 16 & 12 & 4 & 11 \\
9 & 50 & 37 & 10 & 11 & 5 & 5 \\
10 & 50 & 38 & 16 & 11 & 6 & \\
\hline
\end{tabular}

${ }^{a}$ Of these 7 were intersexes and one indifferent.

that there is interaction between larvae cultured in batches as shown by the average of $10.4 \%$ attached males over all the batches. The significance of this finding will be further considered in the discussion. The results also prove conclusively that this interaction produces a high percentage of masculinization of indifferent larvae. Thus, while in the individual cultures the percentage of full masculinization was $2.3 \%$, the average in batch cultures was $27.5 \%$. The $2.3 \%$ masculinized in individual cultures represents the ratio 
of genetic males in the sample. In addition, the individual cultures resulted in $8 \%$ intersexes and $1.1 \%$ indifferent, the rest $(88.6 \%)$ being females.

\section{THE MASCULINIZING SUBSTANCE}

Experiment 3 showed that the percentages of males and intersexes were significantly higher $(P<0.005)$ for the bonellin solution, the crude tissue extracts, and the trunk

\section{TABLE III}

Experiment 3: effects of various substances on the sexual differentiation of single larvae of Bonellia viridis; temperature $18 \pm 1{ }^{\circ} \mathrm{C}$; the bonellin concentrations were restored every $48 \mathrm{~h}$; experiment terminated after 57 days.

\begin{tabular}{lcccccc}
\hline \multicolumn{1}{c}{ Medium } & $\begin{array}{c}\text { No. of } \\
\text { larvae }\end{array}$ & Survivors & Females & Males & Intersexes & Indifferent \\
\hline $10^{-6}$ M bonellin & 50 & 39 & 14 & 11 & 12 & 2 \\
Proboscis extract & 50 & 45 & 15 & 8 & 20 & 2 \\
Trunk extract & 50 & 47 & 6 & 17 & 23 & 1 \\
Trunk secretion & 50 & 48 & 0 & 45 & 1 & 2 \\
Sea-water control & 50 & 48 & 42 & 2 & 0 & 4 \\
\hline
\end{tabular}

secretion of the adult female than for pure sea water. There was no significant difference at the $5 \%$ level between the masculinizing effect of the bonellin solution and that of the proboscis and trunk extracts. The trunk secretion gave a significantly higher masculinization than the bonellin solution and than both tissue extracts (in all cases, $P<0.025$ ). Two points, however, must be noted when comparing the activities of bonellin, the tissue extracts, and the trunk secretion. First, while both the bonellin solution and the tissue extracts produced $30.7-48.9 \%$ intersexes and $17.8-36.2 \%$ males, the natural trunk secretion produced only $2.1 \%$ intersexes and $95.7 \%$ full males. The second point concerns the rate of differentiation with the different treatments. With the trunk secretion and the crude tissue extracts, $>80 \%$ of the larvae had metamorphosed by Day 25 of the experiment; with the bonellin solutions and the sea-water controls the rate of differentiation was much slower and $<50 \%$ of the larvae had metamorphosed by Day 40.

Experiments 4A-D gave inconsistent results. A statistically significant level of masculinization was obtained only in Experiment $A(P<0.01)$. Experiment $D$ showed that the presence or absence of light had no effect on the sexual differentiation of indifferent larvae either in the presence of bonellin or in pure sea water.

\section{DisCUSSION}

One of the more interesting findings of the present work is that the indifferent larvae can interact with one another and that this interaction can play a directive rôle in sexual 
differentiation. This can be deduced from the increased percentage of males $(20.8 \%)$ in batch sea water cultures when compared with the percentage $(7.5 \%)$ differentiating into males when cultured as single individuals (taking into account only those cultures in which losses were $<33 \%$ ). That the increased masculinization is due to interaction between larvae is supported by the observation that up to $20 \%$ of larvae in batch cultures become attached in pairs. It is thus rather surprising that Baltzer (1935) states: "Larvae cannot fix themselves upon embryonic females". This interaction between larval males and females complicates the analysis of the effect of different treatments on the indifferent larvae in batch cultures. In spite of this, our results using isolated larvae confirm the main conclusions of Baltzer $(1928,1931 \mathrm{~b}, 1935)$ and Leutert (1974, 1975), namely, that in the majority of larvae sexual determination is metagamic, i.e., is not determined at fertilization but is dependent on environmental factors. The natural environmental factor is the presence or absence of a masculinizing stimulus normally due to a substance produced by the adult female. Agius (1979) has shown that the female trunk is as effective as the proboscis in this respect. We have also confirmed the presence of a smaller percentage of syngamic larvae, i.e., larvae whose sex (male, female or intersex) is fully determined at fertilization. The existence of syngamic males is shown by the differentiation of a small proportion of larvae $(2-18 \%$, with a mean of $8.4 \%)$ into males when cultured in isolation in pure sea water (Experiments 2,3, and 4). The existence of syngamic females is shown by the development of a larva into a female in the presence of an adult female (Experiment 2). This confirms the findings of Agius (1979) who reported the development of a small proportion of trochophores $(4-6 \%)$ into females in the presence of the entire female as well as in the presence of a proboscidectomized female or its isolated proboscis. We have also established the existence of syngamic intersexes. These are those larvae which develop into intersexes when cultured in isolation in pure sea water. The mean ratio of such intersexes obtained by combining our data with those of Agius (1979) is $2.4 \%$. It must be noted that the experimental design used by Baltzer and by Leutert did not exclude a sex-determining interaction between indifferent larvae cultured in the absence of an adult female or adult female tissue extracts since these workers invariably used batch cultures. Therefore, while our conclusions agree with those of Baltzer and Leutert, our results provide the first unambiguous evidence for the existence of syngamic males and intersexes (i.e. individuals whose sexual differentiation is determined at fertilization). Thus sex determination in $B$. viridis appears to have a genetic component, and whether it is syngamic or metagamic would depend on the relative proportions of the respective sex alleles. This interpretation is in basic agreement with that of Baltzer (1931b), Bacci (1965), and Leutert (1975). Because of the foregoing it is suggested that the expression "phenotypic sex determination" with respect to Bonellia is inappropriate and should be abandoned.

Our experiments with randomized indifferent larvae cultured as isolated individuals disprove conclusively the suggestion of Wilczynski $(1960,1968)$ that the eggs of Bonellia are sexually dimorphic and that the larvae which attach themselves to the females have 
already been previously determined to develop in the male direction.

It should be noted that there was a small percentage of larvae (an average of $6.6 \%$ ) which remained sexually undifferentiated in all the pure sea water individual cultures (Experiments 2-4) in spite of the fact that most of the experiments were not terminated before the number of undifferentiated larvae had remained constant for at least $1 \mathrm{wk}$, and some cultures were maintained for as long as 68 days. Similar observations were made by all previous workers using batch cultures (Baltzer, 1925, 1928, 1935; Herbst, 1929; Leutert, 1974). The question arises whether these larvae are to be considered incapable of sexual differentiation or whether they would ultimately have differentiated sexually. The proportion of such indefinitely indifferent larvae in cultures with the adult female goes down to $3.5 \%$. Therefore, at least about half the residual indifferent larvae in the control cultures were capable of differentiating in the male direction. If we assume that the remaining $3.1 \%$ are incapable of sexual differentiation and add these to the ratios of syngamic males, females and intersexes we get a total of $16.7 \%$ of all larvae whose sex determination is not metagamic, leaving $83.3 \%$ of all larvae with metagamic sex determination.

Two other general observations must be stressed. The first is that larvae of the same spawning do not metamorphose at the same rate. Quite apart from indefinitely indifferent larvae, syngamic males invariably differentiate later than the rest of the larvae of the same spawning. These correspond to Baltzer's "Spătmannchen" (Baltzer, 1931b). The second observation is the great variability in the rate of differentiation under the same environmental conditions between larvae of different spawnings. Thus for instance, Experiment $4 \mathrm{D}$ could be terminated after 24 days, but Experiment $4 \mathrm{C}$ only after 68 days. These observations point to a great lability in the differentiating system, which is presumably a consequence of polygenic control of sex differentiation. Evidence for this will now be discussed.

It is instructive to draw a parallel between the situation in $B$. viridis and that in the consecutive hermaphroditic polychaete Ophryotrocha puerilis. In $O$.puerilis each individual initially goes through a purely male phase, then a morphologically hermaphroditic phase followed by a female phase. This is sometimes followed by a short final male phase. The transition from male to female takes place in many individuals when they have reached a mean length of 18-20 chaetigerous segments (Hartmann \& Huth, 1936; Bacci, 1965). When two female phase individuals are cultured together in a small container, the less ripe female phase individual reverts to the male phase, so that a male-female pair is produced (Hartmann \& Lewinski, 1940; Bacci, 1952). This "pair culture" effect is quite similar to the interaction between indifferent larvae of Bonellia viridis reported here (Experiments 1 and 2) and to the interaction between indifferent larvae and the adult female Bonellia.

The work of Muller (1962) and Pfannenstiel (1977a, 1978) has proved that direct contact is needed for the transmission of a stimulus, presumably a pheromone, leading to the reversal of one member of a pair of female phase Ophryotrocha puerilis to the male phase. In Bonellia the masculinizing factor though normally transmitted by contact can 
be released into and taken up from the surrounding medium (Experiment 3 ). In $O$. puerilis extirpation and transplantation experiments provide strong evidence that in isolated individuals a gonadotrophic hormone found in female phase individuals is involved in feminization and without this hormonal stimulus spermatocytes only are produced (Pfannenstiel, 1973, 1975). In pair cultures this ootrophic hormone is inhibited in one partner by the stimulus coming from the other (female) partner. This situation is paralleled in Bonellia by the fact that most individuals cultured in isolation differentiate into females (Experiment 2) and most are only masculinized in the presence of a female (Experiment 1) or its secretions (Experiment 3).

By selective breeding experiments on Ophryotrocha puerilis Bacci $(1975,1978)$ was able to select for individuals with a long duration of the male phase (arrhenogenous) and individuals with an early onset of the female phase (thelygenous) and eventually obtained genetically pure males (i.e., with no female phase) and genetically pure females (with no male phase). These correspond to the syngamic males and females in Bonellia viridis with the difference that the latter must be present in the wild populations and are not the result of artificial selection.

In Ophryotrocha puerilis crosses between the selectively bred pure male and pure female individuals were highly fertile and produced offspring which were composed of hermaphroditic individuals only and which were heterotic (Bacci, 1975, 1978). Thus, polygenic sex determination was proved. Bacci's work has established that in $O$. puerilis the polygenic sex complement of the individual provides a reaction norm whose specific phenotypic expression depends on environmental factors. Pfannenstiel $(1976,1977 \mathrm{~b}$, 1978) has provided evidence for a fundamentally similar situation in $O$. labronica. Extirpation and transplantation experiments show that the larvae from a single spawning show different degrees of stability of sex determination. Crossing experiments within a protandric population of $O$. labronica suggest that there is a genetic component in the degree of protandry and sex determination.

It is difficult to do breeding experiments with Bonellia because, for one thing, the female takes at least two years to reach sexual maturity. The parallel features found in Bonellia and Ophryotrocha suggest, however, that the genetic mechanism underlying sexual differentiation in $B$. viridis is very likely to be essentially similar to that of Ophryotrocha, i.e., polyfactorial, resulting in multiple sex genotypes. In the case of the consecutive hermaphrodite $O$. puerilis, functional germ cells of both sexes are produced by each individual during its life history, while in the case of Bonellia viridis most individuals are able to produce both male and female gametes depending on the environmental conditions to which the indifferent larvae are exposed. This similarity had already been suggested by Bacci (1965).

The existence of multiple sex genotypes in both Ophryotrocha and Bonellia would also account for the extreme lability of sex determination in both species. Thus, Herbst (1929, $1932,1935,1936,1937)$ showed that simple chemical factors such as the presence of excess $\mathrm{CO}_{3}^{2-}, \mathrm{H}^{+}, \mathrm{K}^{+}$and $\mathrm{Cu}^{2+}$ or the absence of $\mathrm{Mg}^{2+}$ and $\mathrm{SO}_{4}^{2-}$ affect the sexual differentiation of Bonellia trochophores. In Ophryotrocha, Hartmann \& Lewinski (1938) showed that $\mathrm{K}^{+}, \mathrm{Cu}^{2+}$, and $\mathrm{Mg}^{2+}$ cause sex reversal. 
In Ophryotrocha, Bacci \& Bortesi (1967) reported that selection for predominance of either the masculinizing or the feminizing genes not only produces pure males and females respectively, but continued selection leads to sterile individuals in which maturation of the germ cells is inhibited. In such sterile individuals the normal expression of the sex genes can be restored if an individual of the opposite sex is introduced into the culture. Bacci \& Bortesi conclude that the presence of factors of both sexes is necessary for the activitation of either the male or female genes and that a pheromone released by an individual of the opposite sex can substitute for the lack of sex genes of the complementary sex within the sterile individual. An analogous effect may be at work in our larval cultures of Bonellia where it is observed that there is a consistently higher percentage of sexually undifferentiated larvae in the pure sea-water cultures than in larvae cultured in the presence of an adult female. It would be interesting to find out whether these residual indifferent larvae are indeed permanently incapable of differentiation. If this were so, it would suggest that they represent individuals with female genes only, and as such, individuals whose genome is incapable of complementation by that of a neighbouring adult female.

The rôle of bonellin in masculinization remains problematical. While in two experiments ( 3 and $4 A$ ) the presence of bonellin was accompanied by a significantly increased percentage of males, in another three (4B to D) this was not the case. The results of Experiment 3 suggest that the isolation and purification procedures for bonellin, as well as the extraction procedures for the proboscis and trunk tissue extracts tested, impair the masculinizing activity of the test substances as compared with the activity of the native secretion of the adult female. It may be, therefore, that the native masculinizing substance is a derivative of bonellin or has bonellin as one of its constituents. The different effects of purified bonellin on larvae of different spawnings may be explained by the existence of multiple sex genotypes. The very potent masculinizing effect of the trunk secretion has already been noted by Agius (1979) and supports Baltzer's original suggestion that a substance produced by the adult female is responsible for the masculinization of the larvae.

Agius et al. (1979) showed that purified bonellin has marked photodynamic activity, haemolyzing erythrocytes, immobilizing spermatozoa, and arresting the development of echinoid and Bonellia eggs. Thus, there was an expectation that if bonellin were involved in masculinization of indifferent larvae it would exert its effect via a photodynamic process. The results of Experiment 4D do not provide evidence for this.

\section{ACKNOWLEDGEMENTS}

This work involved the use of equipment obtained through a grant from the Development Fund of Barclays Bank International towards the setting up of the Fort St. Lucian Marine Station. The authors are grateful to Professor A. Pelter and Dr. A. F. Psaila of the Department of Chemistry, University College of Swansea, U.K. for 
providing the purified bonellin used in this work. Thanks are also due to Messrs C. Galea, J. Portelli, and A. Fenech for technical assistance and Messrs S. Sciberras, J. Debono, and L. Agius for collecting Bonellia.

\section{REFERENCES}

AGIUS, L., 1979. Larval settlement in the echiuran worm Bonellia viridis: settlement on both the adult proboscis and body trunk. Mar. Biol., Vol. 53, pp. 125-129.

Agius, L., V. Jaccarini, J. A. Ballantine, V. Ferrito, A. Pelter, A.F. Psaila \& V. A. Zammit, 1979. Photodynamic action of bonellin, an integumentary chlorin of Bonellia viridis Rolando (Echiura, Bonelliidae). Comp. Biochem. Physiol., Vol. 63B, pp. 109-117.

BaCCI, G., 1952. Diverso comportamento sessuale delle Ophryotrocha puerilis di Napoli e di Plymouth. Boll. Soc. Ital. Biol. Sper., Vol. 28, p. 1293 only.

BACCI, G., 1965. Sex determination. Pergamon Press, Oxford, 306 pp.

BACCI, G., 1975. Genetic and environmental control of sex determination in marine animals. Pubbl. Stn. Zool. Napoli, Vol. 39 Suppl., pp. 366-376.

BACCI, G., 1978. Genetics of sex determination in Ophryotrocha (Annelida Polychaeta). In, Marine organisms: genetics, ecology, evolution, edited by B. Battaglia \& J.A. Beardmore, Plenum Press, New York \& London, pp. 549-571.

BACCI, G. \& O. BorTESI, 1967. The reestablishment of sex balance in Ophryotrocha puerilis through interactions between individuals from arrhenogenous and thelygenous lines. Experientia, Vol. 23, pp. $448-449$.

Ballantine, J.A., A.F. Psaila, A. Pelter, P. Murray-Rust, V. Ferrito, P. Schembri \& V. JACCARINI, 1980. The structure of bonellin and its derivatives. Unique physiologically active chlorins from the marine echiuran Bonellia viridis. J. Chem. Soc. Perkin Trans. 1, pp. 1080-1089.

Baltzer, F., 1914. Die Bestimmung des Geschlechts nebst einer Analyse des Geschlechtsdimorphismus bei Bonellia. Mitt. Zool. Stn. Neapel, Vol. 22, pp. 1-44.

BALTzER, F., 1924. Über die Giftwirkung der weiblichen Bonelliagewebe auf die Bonellia-männchen und andere Organismen und ihre Beziehung zur Bestimmung des Geschlechts der Bonellia-larve. Mitt. Naturf. Ges. Bern, Vol. 8, pp. 98-117.

Baltzer, F., 1925. Über die Giftwirkung der weiblichen Bonellia und ihre Beziehung zur Geschlechtsbestimmung der Larve. Rev. Suisse Zool., Vol. 32, pp. 87-93.

Baltzer, F., 1926. Über die Vermännlichung indifferenter Bonellia-larven durch Bonellia Extrakte. Rev. Suisse Zool., Vol. 33, pp. 359-374.

Baltzer, F., 1928. Uber metagame Geschlechtsbestimmung und ihre Beziehung zu einigen Problemen der Entwicklungsmechanik und Vererbung (auf Grund von Versuchen an Bonellia). Verh. Dtsch. Zool. Ges., Vol. 32, pp. 273-325.

BALTZER, F., 1931a. Entwicklungsmechanische Untersuchungen an Bonellia viridis. Die Abhängigkeit der Entwicklungsgeschwindigkeit und des Entwicklungsgrades der männlichen Larve von der Dauer der Rüssel-parasitismus. Rev. Suisse Zool., Vol. 38, pp. $361 \cdot 371$.

BALTZER, F., 193 lb. Echiurida. In, Handbuch der Zoologie, Bd 2, edited by W. Kükenthal \& T. Krumbach, De Gruyter, Berlin \& Leipzig, pp. 62-168.

BALTZER, F., 1932. Über die ohne Rüssel-parasitismus entstehenden Spätmännchen (genetische Männchen) der Bonellia viridis. Rev. Suisse Zool., Vol. 39, pp. 281-305.

Baltzer, F., 1935. Experiments on sex-development in Bonellia viridis. Collecting Net (Woods Hole), Vol. 10 (3), pp. 1-8.

Cariello, L., M. De Nicola Giudici, L. Zanetti \& G. Prota, 1978. Neobonellin, a new biologically active pigment from Bonellia viridis. Experientia, Vol. 34, pp. 1427-1429.

HartmanN, M. \& W. HuTH, 1936. Untersuchungen über Geschlechtsbestimmung und Geschlechtsumwandlung von Ophryatrocha puerilis. Zool. Jahrb. (Physiol.), Vol. 56, pp. 389439.

HaRTMANN, M. \& G. Lewinski, 1938. Untersuchungen über Geschlechtsbestimmung und Geschlechtsumwandlung von Ophryotrocha puerilis. II. Versuche über die Wirkung von Kalium, Magnesium und Kupfer. Zool. Jahrb. (Physiol.), Vol. 58, pp. 551-574. 
HaRTMANN, M. \& G. LewINSKI, 1940. Untersuchungen über Geschlechtsbestimmung und Geschlechtsumwandlung von Ophryotrocha puerilis. III. Die stoffliche Natur der vermännlichenden Wirkung "starker" Weibchen (Eistoffe). Zool. Jahrb. (Physiol.), Vol. 60, pp. 1-12.

HERBST, C., 1928. Untersuchungen zur Bestimmung des Geschlechts. I. Mitteilung: ein neuer Weg zur Lösung des Geschlechtsbestimmungsproblem bei Bonellia viridis. Sitz.-Ber. Heidelberg. Akad. Wiss., Math.-Nat. Kl., Vol. 19 (2), pp. 1-19.

HerbST, C., 1929. Untersuchungen zur Bestimmung des Geschlechts. II. Mitteilung: weitere Experimente über die Vermännlichung indifferenter Bonellia-larven durch künstliche Mittel. Sitz.-Ber. Heidelb. Akad. Wiss., Math.-nat. Kl., Vol. 20 (16), pp. 1-43.

Herbst, C., 1932. Untersuchungen zur Bestimmung des Geschlechts. III. Mitteilung: Die Vermännlichung der Larven durch Kupferspuren. Naturwissenschaften, Vol. 20, pp. 375-379.

Herbst, C., 1935. Untersuchungen zur Bestimmung des Geschlechts. IV. Mitteilung: die Abhängigkeit des Geschlechts von Kaliumgehalt des umgebenden Mediums bei Bonellia viridis. Wilhelm Roux Arch. Entwicklungsmech. Org., Vol. 132, pp. 567-599.

HeRBSt, C., 1936. Untersuchungen zur Bestimmung des Geschlechts. V. Mitteilung: die Notwendigkeit des Magnesiums für die Lebenserhaltung und die Weiterentwicklung der Bonellia-larven und seine Bedeutung für die geschlechtliche Differenzierung derselben. Wilhelm Roux Arch. Entwicklungsmech. Org., Vol. 134, pp. $313-330$.

Herbst, C., 1937. Untersuchungen zur Bestimmung des Geschlechts. VII. Mitteilung: über die Bedeutung des $\mathrm{SO}_{4}$-ions für die Weiterentwicklung und geschlechtliche Differenzierung der Bonellia-larven und den Einfluss der erhöhten Ca-gehaltes in $\mathrm{SO}_{4}$-armen Medium auf diese Prozesse. Wilhelm Roux Arch. Entwicklungsmech. Org., Vol. 136, pp. 147-168.

LAllier, R., 1955. Recherches sur la toxicité des extraits du ver marin Bonellia viridis. C.R. Acad. Sci., Vol. 240, pp. 1489-1491.

LEUTERT, R., 1974. Zur Geschlechtsbestimmung und Gametogenese von Bonellia viridis Rolando.J. Embryol. Exp. Morphol., Vol. 32, pp. 169-193.

LEUTERT, R., 1975. Sex determination in Bonellia. In, Intersexuality in the animal kingdom, edited by R. Reinboth, Springer-Verlag, Heidelberg, pp. 84-90.

Loosti, M., 1935. Úber die Entwicklung und den Bau der indifferenten und männlichen larven von Bonellia viridis Rolando. Pubbl. Stn. Zool. Napoli, Vol. 15, pp. 16-58.

MÚller, H., 1962. Über die Sexualität des Polychaeten Ophryotrocha puerilis, ihre Determination und ihren Einfluß auf Drüsentätigkeit und Kauapparatentwicklung. Z. Morphol. Ökol. Tiere, Vol. 52, pp. 1-32.

MUTSCHELleR, F., 1935. Experimentelle Untersuchung der Organe der Weibchen von Bonellia viridis, deren Extrakte vermännlichend wirken, auf das Vorkommen Schwermetallen insbesondere von Kupfer. Biol. Zentralbl., Vol. 55, pp. 615-625.

Nigrelli, R.F., M.S. Stempien, G.D. Ruggieri, V.R. Liguori \& J.T. Cecil, 1967. Substances of potential biomedical importance from marine organisms. Fed. Proc. Fed. Am. Soc. Exp. Biol., Vol. 26, pp. 1197-1205.

NowINSKI, W., 1934. Die vermännlichende Wirkung fraktionierter Darm-extrakte der Weibchens auf die Larven der Bonellia viridis. Pubbl. Stn. Zool. Napoli, Vol. 14, pp. 110-145.

Pelter, A., J.A. Ballantine, V. Ferrito, V. Jaccarini, A. F. Psaila \& P. J. Schembri, 1976. Bonellin, a most unusual chlorin. J. Chem. Soc. Chem. Commun., Vol. 23, pp. 999-1000.

Pelter, A., A. Abela-Medici, J. A. Ballantine, V. Ferrito, S. Ford, V. Jaccarini \& A. F. Psaila, 1978a. The structure of amino-acid conjugates of bonellin derived from the marine echiuroid Bonellia viridis. Tetrahedron Lett., Vol. 23, pp. 2017-2020.

Pelter, A., J.A. Ballantine, P. Murray-Rust, V. Ferrito \& A. F. Psaila, 1978b. The structure of anhydrobonellin and bonellin, the physiologically active pigment from the marine echiuroid Bonellia viridis Tetrahedron Lett., Vol. 21, pp. 1881-1884.

Pfannenstiel, H.-D., 1973. Zur sexuellen Differenzierung von Ophryotrocha puerilis (Polychaeta : Eunicidae). Mar. Biol., Vol. 20, pp. 245-258.

PfanNenstiel, H.-D., 1975. Mutual influence on the sexual differentiation in the protandric polychaete Ophryotrocha puerilis. In, Intersexuality in the animal kingdom, edited by R. Reinboth, Springer-Verlag, Heidelberg, pp. 48-56.

Pfannenstiel, H.-D., 1976. Ist der Polychaet Ophryotrocha labronica ein proterandrischer Hermaphrodit? Mar. Biol., Vol. 38, pp. 169-178. 
Pfannenstiel, H.-D., 1977a. Experimental analysis of the "Paarkultureffekt" in the protandric polychaete, Ophryotrocha puerilis Clap. Mecz. J. Exp. Mar. Biol. Ecol., Vol. 28, pp. 31-40.

Prannens IItL, H.-D., 1977b. Endokrinologische und genetische Untersuchungen an einer proterandrischen Population des Polychaeten Ophryotrocha labronica. Mar. Biol., Vol. 39, pp. 319-329.

PfanNenstiel, H.-D., 1978. Endocrinology of polychaete reproduction and sexual development. Boll. Zool., Vol. 45, pp. 171-188.

SCHEMBRI, P.J., 1977. Aspects of the biology of the echiuran worm Bonellia viridis. M.Sc. thesis, University of Malta, $224 \mathrm{pp}$.

SpenGel, J.W., 1879. Beiträge zur Kenntniss der Gephyreen. I. Die Eibildung, die Entwicklung und das Männchen der Bonellia. Mitt. Zool. Stn. Neapel, Vol. 1, pp. 357-420.

WILCZYNSK1, J., 1960. On the egg dimorphism and sex determination in Bonellia viridis. J. Exp. Zool., Vol. 143, pp. 61-76.

WILCZYNSKI, J., 1968. On the sex in Bonellia viridis. Acta Biotheor., Vol. 18, pp. 338-370.

ZURBUCHEN, K., 1937. Entwicklungsmechanische Untersuchungen an Bonellia viridis. 2. Entwicklung der Intersexe und sexuelle Variabilität bei Bonellia viridis in Versuchen mit abgekurztem Rüsselparasitismus. Pubhl. Stn. Zool. Napoli, Vol. 16, pp. 28-80. 